\title{
Studies of Foliar Nutrients on Productivity and Quality of Wheat Seed (Triticum aestivum L.) under Lower Gangetic Alluvial Soils of West Bengal, India
}

\author{
Dhritiman Das* and R.B. Mallick
}

Department of Agronomy, Institute of Agricultural Science, University of Calcutta, 51/2 Hazra Road, Kolkata - 700019, West Bengal, India

*Corresponding author

\begin{tabular}{|l|}
\hline Ke y w or d s \\
Foliar application, \\
Micronutrients, \\
wheat \\
\hline Article Info \\
\hline Accepted: \\
12 May 2019 \\
Available Online: \\
10 June 2019 \\
\hline
\end{tabular}

\section{A B S T R A C T}

A field experiment was conducted at Agricultural Experimental Farm of Calcutta University, Baruipur, South 24 - Parganas, West Bengal during the during rabi season of 2016 - 2017 on Gangetic Alluvial Soil. The investigation was designed to study "Studies of foliar nutrients on productivity and quality of wheat (Triticum aestivum L.) seed under lower Gangetic alluvial soils of West Bengal". This investigation was laid out in a Randomized block design with three replications on the Gangetic alluvial soil of lowland under well irrigated condition. There were altogether 10 treatments of supplementary foliar nutrients viz. $\mathrm{KCl} @ 0.75 \% ; \mathrm{KNO}_{3} @ 0.75 \% ; \mathrm{KNO}_{3} @ 1 \% ; \mathrm{N}: \mathrm{P}: \mathrm{K} @ 1 \% ; \mathrm{N}: \mathrm{P}: \mathrm{K} @$ 1.5\%; $\mathrm{NaCl} @ 0.5 \% ; \mathrm{NaCl} @ 0.75 \% ; \mathrm{K}_{2} \mathrm{SO}_{4} @ 0.5 \%$; $\mathrm{K}_{2} \mathrm{SO}_{4} @ 0.75 \%$ along with water spray at $50 \%$ flowering and grain filling stages. The result in general, indicates that foliar applications of nutrients had a great influence on yield contributing characters and grain yield of wheat. The investigation clearly shows that significantly highest seed yield was recorded with foliar application of $\mathrm{NaCl} @ 0.5 \%$. Simultaneously lowest seed yield observed from only water sprayed control treatment. The seed yield was increased up to $27.92 \%$ with the application of $\mathrm{NaCl} @ 0.5 \%$. Similar trends were also noticed in yield contributing characters of the crop. Sole application of nutrients viz. $\mathrm{NaCl} @ 0.5 \%$; NaCl @ 0.75\%; KCl @ 0.75\%; $\mathrm{KNO}_{3} @ 0.75 \% ; \mathrm{KNO}_{3} @ 1 \% ; \mathrm{N}: \mathrm{P}: \mathrm{K} @ 1 \% ; \mathrm{N}: \mathrm{P}: \mathrm{K} @ 1.5 \%$; $\mathrm{K}_{2} \mathrm{SO}_{4} @ 0.5 \% ; \mathrm{K}_{2} \mathrm{SO}_{4} @ 0.75 \%$ at $50 \%$ flowering on wheat was also recorded statistically higher grain yield and higher protein content over water sprayed control treatment. The findings found at this study can be used in management recommendations of wheat.

\section{Introduction}

Wheat, a fine cereal, has played a stellar role in India's transformation from its ship-tomouth existence of the 1960s to exporting grains as at present. With an output of 96.64 million tons harvested from 31.19 million hectares in 2016-17, the country has emerged as the world's second largest producer of wheat. With the advent of terminal heat stress (sudden rise in temperature during grain filling period) adversely affecting wheat grown on 36 million ha area, comprising 40\% of the temperate environment (Hays et al., 
2007), there is sheer urgency to find the mitigation strategies. The current trends in India also indicate that the 'cool period' for wheat crop is shrinking, while the threat of terminal heat stress is increasing (Joshi et al., 2007). Delayed sowing of wheat due to late harvesting of rice is one of the main reasons for terminal heat stress in eastern part of India. Heat stress is an important constraint to wheat productivity affecting different growth stages specially anthesis and grain filling. Shriveled small grains are produced and different yield associated traits such as grain weight and grains numbers/spike is reduced. Biological yield, harvest index and spike length are severally decreased (Suryavanshii et al., 2016). In West Bengal, the rise in temperature during critical stages of wheat is also leading to less production. Foliar fertilization is an important tool for the sustainable and productive management of crops. Furthermore, foliar fertilization is theoretically more environmentally friendly, immediate and target-oriented than soil fertilization.

It should be widely adopted in modern crop management where it should be used to ensure optimal crop performance when nutrient supply from the soil is inadequate or uncertain. Foliar fertilizers offer specific advantages over soil fertilizers when plant demand for nutrients exceeds the capacity for root nutrient uptake; when elemental mobility within the plant limits delivery to tissues; and when environmental conditions limit the effectiveness or prevent the application of nutrients to the soil. In many risk-averse, high-value production systems foliar fertilizers are marketed as 'insurance' to minimize the potential impacts of unpredictable nutrient deficiencies. Moreover, there is an increase in protein percentage of seed and yield components due to foliar application. Das and Sarkar (1978) demonstrated that the post flowering spraying of $\mathrm{NaCl}$ solution in the late grain filling stage of wheat resulted in high grain yield through more translocation of photo synthates, especially the strode ones, to the developing grains. Several studies showed $\mathrm{Cl}^{-}$fertilizer, basically applied in the form of $\mathrm{KCl}$, improved the productivity of wheat and other crops in the Great Plains. Freeman and Girma (2006) reported $\mathrm{Cl}$ fertilizer significantly increased wheat grain yields in $50 \%$ of the sites with 0,15 and $30 \mathrm{~kg} \mathrm{Cl} \mathrm{ha}^{-1}$ rates, and the increases were more notable on the sandy loam soil. However, numerous reports indicate a significant stimulation in the growth of many crops in response to $\mathrm{Na}$, even under conditions of K-sufficiency. Foliar application is credited with the advantage of quick and efficient utilization of nutrients, eliminating losses through leaching, and fixation and helps in regulating the uptake of nutrients by plants (Manomani and Srimath, 2009).

There also is convincing evidence that $\mathrm{Na}$ can substitute for $\mathrm{K}$ in non-specific functions, such as being an osmoticum during cell enlargement and as a counter ion during longdistance transport. In the above roles, $\mathrm{Na}$ influences plant growth in a very significant way both as to growth rate and in efficient nutrient resource utilization. In the above roles, $\mathrm{Na}$ influences plant growth in a very significant way both as to growth rate and in efficient nutrient resource utilization. The functional role of $\mathrm{Na}$ in plant nutrition can be large, multi-faceted and of critical importance in both natural bio-systems and controlled plant production systems. Previously, many reports have estimated the wheat response to exogenous application of micronutrients (both soil and foliar applied), but a little is known regarding combined application of micronutrients. Therefore, the objective of this study is to check the effect of foliar application of nutrients on seed quality and yield of wheat. 


\section{Materials and Methods}

The present experiment designed to study the performance of wheat (Triticum aestivum L.) as affected by spraying of different salt solution at $50 \%$ flowering was conducted at the Agricultural Experimental Station of Calcutta University, Baruipur, South 24 Parganas, West Bengal ( $88^{\circ} 26^{\prime}$ E Longitude and $22^{\circ} 22^{\prime}$ North Latitude) during the Rabi season (December to April) of 2016-17. The soil of experimental plot was medium fertility, clay loam in texture, having $1.0 \%$ organic carbon, available phosphorus $34.18 \mathrm{~kg} / \mathrm{ha}$ and available potassium $278 \mathrm{~kg} / \mathrm{ha}$ with a $\mathrm{pH}$ of 6.35. HD 2967 is a double dwarf variety with an average plant height of 101 $\mathrm{cm}$ was used.

The treatments were assigned using randomized block design (RBD) with three replications on 10 different levels of foliar sprays including control check T1 (no spray), $\mathrm{T} 2 \mathrm{KCl}$, @0.75\%, T3 $\mathrm{KNO}_{3} @ 0.75 \%, \mathrm{~T} 4$ $\mathrm{KNO}_{3} @ 1.0 \%, \mathrm{~T} 5 \mathrm{~N}: \mathrm{P}: \mathrm{K} @ 1.0 \%, \mathrm{~T} 6 \mathrm{~N}: \mathrm{P}:$ K@1.5\%, T7 NaCl@0.5\%, T8 NaCl@ $0.75 \%, \quad \mathrm{~T} 9 \quad \mathrm{~K}_{2} \mathrm{SO}_{4} @ \quad 0.5 \%, \quad \mathrm{~T} 10$ $\mathrm{K}_{2} \mathrm{SO}_{4} @ 0.75 \%$. The fertilizer was applied @ $100 \mathrm{Kg} \mathrm{N}, 50 \mathrm{Kg} \mathrm{P}_{2} \mathrm{O}_{5}$ and $50 \mathrm{Kg} \mathrm{K}_{2} \mathrm{O} / \mathrm{ha}$ in the form of urea, single super phosphate and muriate of potash respectively. The crop was irrigated with tube well water throughout the growth period. Necessary plant protection measures and agronomic practices were done whenever required. The crop was harvested at maturity and data on tillering, plant height, numbers of filled grains, 1000-grain weight, protein content and wheat yields were recorded. Data were analyzed statistically and differences determined using the LSD test (Gomez and Gomez, 1984).

\section{Results and Discussion}

Data presented in (Table 1) indicated that all the treatments have significantly recorded higher grain yield and its components as compared to control. Total number of grains/panicle in $\mathrm{NaCl} @ 0.5 \%$ treated plots was found to be highest (40.68) in comparison to other foliar nutrient treatments which were $36.63 \%$ more than the control. Similarly, all the foliar nutrient treatments recorded significantly higher test weight over water spray control treatment. Test weight was highest $\mathrm{NaCl} @ 0.5 \%$ treated plot $(43.80 \mathrm{~g})$ which is $8.59 \%$ more than the water spray control. Seed yield was meaningfully affected due to foliar application of micronutrients in spite of unfavorable weather condition throughout the sowing and grain filling season, The highest seed yield (2840 $\mathrm{kg} / \mathrm{ha}$ ) was observed with foliar spray application of $\mathrm{NaCl} @ 0.5 \%$ followed by $\mathrm{NaCl} @ 0.75 \%$. But statistically these two treatments are at par.

All the foliar nutrition treatments enhanced seed yield significantly over control treatment. Spraying of only KCL @ $0.75 \%$ concentration increased seed yield significantly over control by $11.56 \%$. The increased seed yield might be due to enhanced partitioning efficiency and correcting transient nutrient deficiency during flowering and post flowering i.e. grain filling stage. Rahman et al., (2014) found that the foliar treatment of $\mathrm{KCl}$ along with $\mathrm{N}$ results in maximum biological yield. The investigation revealed that both potassium sources i.e. $\mathrm{KCl}$ and $\mathrm{KNO}_{3}$ are similar efficient in maximizing the wheat yield. Increased application of $\mathrm{K}+$ has been shown to enhance photosynthetic rate, growth, yield and drought resistance in different crops under abiotic stress conditions (Egilla et al., 2001) Seed quality parameters as presented in (Table 1) shows significant impact by foliar application treatments, Best result with respect to germination of wheat seed was observed with foliar application of $\mathrm{NaCl} @ 0.5 \%$ (Table 1) which was closely followed by $\mathrm{NaCl} @ 0.75 \%$. 
Table.1 Effect of treatments on germination, root length, shoot length, seedling length and vigour index

\begin{tabular}{|c|c|c|c|c|c|}
\hline Treatments & $\begin{array}{c}\text { Germination } \\
(\%)\end{array}$ & $\begin{array}{l}\text { Mean Root } \\
\text { Length }(\mathbf{C m})\end{array}$ & $\begin{array}{l}\text { Mean Shoot } \\
\text { Length }(\mathbf{C m})\end{array}$ & $\begin{array}{l}\text { Mean Seedling } \\
\text { Length }(\mathbf{C m})\end{array}$ & Vigour Index \\
\hline T1-Control & 83.33 & 7.81 & 9.02 & 16.83 & 1401.94 \\
\hline $\mathrm{T}_{2} \mathrm{kcl} @ 0.75 \%$ & 86.66 & 8.71 & 9.09 & 17.81 & 1541.48 \\
\hline $\mathrm{T}_{3}-\mathrm{KNO}_{3} @ 0.75 \%$ & 86.66 & 8.13 & 9.46 & 17.59 & 1523.29 \\
\hline $\mathrm{T}_{4}-\mathrm{KNO}_{3} @ 1.0 \%$ & 86.66 & 9.07 & 9.79 & 18.86 & 1633.28 \\
\hline T5-N:P:K @ 1\% & 80 & 8.60 & 10.01 & 18.61 & 1488.80 \\
\hline $\mathrm{T}_{6}-\mathrm{N}: \mathrm{P}: \mathrm{K} @ \mathbf{1 . 5 \%}$ & 83.33 & 8.95 & 9.72 & 18.68 & 1555.21 \\
\hline T7-Nacl @ 0.5\% & 90 & 10.05 & 10.55 & 20.61 & 1854.00 \\
\hline $\mathrm{T}_{8}$-Nacl @ 0.75\% & 90 & 9.44 & 9.87 & 19.310 & 1737.90 \\
\hline $\mathrm{T}_{9}-\mathrm{K}_{2} \mathrm{SO}_{4} @ 0.5 \%$ & 90 & 8.08 & 9.28 & 17.36 & 1562.40 \\
\hline $\mathrm{T}_{10}-\mathrm{K}_{2} \mathrm{SO}_{4} @ 0.75 \%$ & 96.66 & 8.99 & 9.47 & 18.46 & 1783.24 \\
\hline C.D. $(0.05)$ & NS & NS & NS & NS & - \\
\hline
\end{tabular}

Table.2 Effect of treatments on number of filled grains (seeds), test weight and seed yield of wheat

\begin{tabular}{|c|c|c|c|c|}
\hline Treatments & $\begin{array}{c}\text { Filled } \\
\text { Grains/Panicle }\end{array}$ & $\begin{array}{l}\text { Test Weight } \\
\text { (G) }\end{array}$ & $\begin{array}{c}\text { Seed Yield } \\
(\mathrm{Kg} / \mathrm{Ha})\end{array}$ & $\begin{array}{l}\text { \% Increase Yield } \\
\text { Over Control }\end{array}$ \\
\hline $\mathbf{T}_{1}$-Control & 29.78 & 40.33 & 2220 & ------------- \\
\hline $\mathrm{T}_{2} \mathrm{kcl} @ 0.75 \%$ & 37.75 & 42.77 & 2660 & 19.81 \\
\hline $\mathrm{T}_{3}-\mathrm{Kno}_{3} @$ @ 0.75\% & 38.01 & 41.57 & 2480 & 11.71 \\
\hline $\mathrm{T}_{4}-\mathrm{Kno}_{3} @ 1.0 \%$ & 36.95 & 42.27 & 2420 & 9.00 \\
\hline $\mathrm{T}_{5}-\mathrm{N}: \mathrm{P}: \mathrm{K} @ 1 \%$ & 37.98 & 42.51 & 2380 & 7.20 \\
\hline$T_{6}-\mathrm{N}: P: K @ 1.5 \%$ & 38.02 & 42.87 & 2370 & 6.75 \\
\hline $\mathrm{T}_{7}$-Nacl @ 0.5\% & 40.68 & 43.80 & 2840 & 27.92 \\
\hline $\mathrm{T}_{8}$-Nacl @ 0.75\% & 38.42 & 43.62 & 2790 & 25.67 \\
\hline $\mathrm{T}_{9}-\mathrm{K}_{2} \mathrm{SO}_{4} @ 0.5 \%$ & 37.93 & 42.33 & 2370 & 6.75 \\
\hline $\mathrm{T}_{10}-\mathrm{K}_{2} \mathrm{SO}_{4} @ 0.75 \%$ & 36.46 & 42.62 & 2320 & 4.50 \\
\hline C.D. (0.05) & 0.59 & 0.93 & 0.035 & \\
\hline
\end{tabular}

The data on MRL and MSL clearly showed that all the foliar nutrients application significantly increased that two important characters of seed quality and maximum total seedling length was recorded under foliar application of $\mathrm{NaCl} @ 0.5 \% ; \mathrm{NaCl} @ 0.75$ $\% ; \mathrm{N}: \mathrm{P}: \mathrm{K} @ 1 \%$; N: P: K @ 1.5\% etc. With regards to vigor index, similar trend was observed and again foliar spray with $\mathrm{NaCl} @$ $0.5 \%$ found to be the best treatment.
Considering the aforementioned facts, it could be concluding that the foliar application by $\mathrm{NaCl}, \mathrm{KNO}_{3}, \mathrm{KCl}, \mathrm{N}: \mathrm{P}: \mathrm{K}$ and their combination increased grain yield (Table 2 ).

It could be concluded from the study that foliar applications of nutrients had a great influence on yield contributing characters and grain yield of wheat. Hence, the post flowering foliar application of $\mathrm{NaCl} @ 0.5 \%$ 
at $50 \%$ flowering and grain filling stages is found to be beneficial to increase the grain yield and seed quality of wheat.

\section{References}

Bameri, M., Abdolshahi, R., MohammadiNejad, G., Yousefi, K. and Tabatabaie, S. M. 2012. Effect of Different Microelement Treatment on Wheat (Triticum aestivum L.) Growth and Yield. Int Res J. of Basic and Appl. Sci, 3, 219-223.

Das, S. and Sarkar, A.K. 1981. Effect of post flowering spray of $\mathrm{KNO}_{3}$ solution of grain filling and yield of rice and wheat, Indian Agric., 25, 267 - 273.

Egilla, J. N., Jr, D. F.T., Drew, M. C. 2001. Effect of potassium on drought resistance of Hibiscus rosa sinensis cv. Leprechaun: Plant growth, leaf macroand micronutrient content and root longevity. Pl and Soil, 229(2): 213-224.

Gomez, K. A., Gomez, A. A. 1984. Statistical Procedures for Agricultural Research. 704 pp., 2nd edition, John Wiley \& Sons, Inc. New York, USA.

Hays, D. E., Mason, J., HwaDo, M. and Reynolds, M. 2007. Expression in quantitative trait loci mapping heat tolerance during reproductive development in wheat. (In) Wheat Production in Stressed Environments, (pp 373-82). H T J Buck, Nisi. E and
Salomon N (eds) Springer, Netherlands. Joshi, A. K., Mishra, B., Chatrath, R., Ferrara, G. O. and Singh, R. P. 2007. Wheat improvement in India: Present status, emerging challenges and future prospects. Euph, 157: 431-46.

Manomani, V. and Sirmathi, P. 2009. Influence of mother crop nutrition on seed and quality of blackgram. Madras Aric. J., 96(1-6): 125-128.

Rehm, G. and Sims, A.2006. Micro-nutrients and production of hard red spring wheat. Minnesota Crop News, Univ. of Minnesota.

Rahman, I. U. R., Afzal, A., Iqbal, Z. and Manan, S. 2014. Foliar Application of Plant Mineral Nutrients on Wheat: A Review. Research and Reviews: $J$ of Agri and Allied Sci. 3(2): 19-22.

Strong, W. M. 1982. Effect of late application of nitrogen on the yield and protein content of wheat. Aus. J. Exper. Agric. Animal Husbandry. 22(115): 54 - 61.

Suryavanshii, P., Buttar, G. S and Brar, A. S. 2016. Effect of osmo protectants on performance of wheat (Triticum aestivum) under terminal heat stress condition of North-West India. Ind. J. Agric. Sci. 86 (8): 1037-42

Liew, C.S. 1988. Foliar Fertilizers from Uniroyal and their Potential in Pakistan. Proceedings of Seminar on Micronutrient in Soils and Crops in Pak. Pp. 277.

\section{How to cite this article:}

Dhritiman Das and Mallick, R.B. 2019. Studies of Foliar Nutrients on Productivity and Quality of Wheat Seed (Triticum aestivum L.) under Lower Gangetic Alluvial Soils of West Bengal, India. Int.J.Curr.Microbiol.App.Sci. 8(06): 1364-1368. doi: https://doi.org/10.20546/ijcmas.2019.806.165 